\title{
MENINGKATKAN HASIL BELAJAR PUSH UP, SIT UP DAN PULL UP DENGAN VIDEO TUTORIAL PADA MAHASISWA PJKR UKAW KUPANG
}

\author{
Alventur Baun', Yahya Jecson Palinata² Julian J. Leko ${ }^{3}$ Isak Riwu Rohi ${ }^{4}$ \\ Universitas Kristen Artha Wacana Kupang ${ }^{1,2,3,4}$ \\ alventurbaun@yahoo.co.id
}

\begin{abstract}
ABSTRAK
Tujuan penelitian ini untuk mengetahui apakah ada peningkatan hasil belajar sit up, pull up dan push up pada mahasiswa. Jenis penelitian yang digunakan adalah penelitian tindakan dan dilaksanakan dengan dua siklus, setiap siklus dimulai dengan perencanaan, tindakan, observasi, dan refleksi. Subjek penelitian ini adalah berjumlah 20 peserta didik. Data dikumpulkan dari hasil observasi dan tes. Hasil penelitian menunjukan bahwa ada peningkatan hasil belajar siswa, terbukti bahwa pada siklus I yang tuntas sebanyak 16 orang dan tidak tuntas sebanya 4 orang dengan dengan rincian kategori Baik sebanyak 6 orang dengan presentase 30\%, kategori Cukup sebanyak 10 orang dengan prsentase 50\%, dan kategori Kurang sebanyak 4 orang dengan presentase 20\%. Pada siklus II semuanya tuntas dengan rincian kategori Baik Sekali sebanyak 2 orang dengan presentase $10 \%$, kategori Baik sebanyak 18 orang dengan prsentase 90\%. Disimpulkan bahwa dengan video tutorial dengan yang diberikan efektif dan dapat meningkatkan hasil belajar mahasiswa.
\end{abstract}

Kata Kunci: Hasil Belajar, Video Tutorial, Tes push up, sit up, dan pull up

\begin{abstract}
The aim of this research is to see students improvement of students learning outcomes push ups, sit ups, and pull ups. The type of this research used is action research and carried out in two cycles, each cycle starting with planning, action, observation, and reflection. The subjects of this research are 20 students. The data are collected from observations result and tests. The results of this research showed that there is an improvement of students learning outcomes, the results are proven in the first cycle there was 16 complete and 4 incomplete with the details of the result Good as many as 6 persons by percentage of 30\%, category of Enough as many as 10 persons by percentage of 50\%, and the category Deficient as many as 4person by percentage of $20 \%$. In the second cycle everything completed with the details of the Excellent category as many as 2 persons with a percentage of 10\%, in the Good category as many as 18 persons by percentage of $90 \%$.The conclusion is that the tutorial videos can give the effectiveness and improvement for student learning outcomes.
\end{abstract}

Keywords: Study Results, Video Tutorials, Test push up, sit up and pull up

Dipublikasikan Oleh :

UPT Publikasi dan Pengelolaan Jurnal

Universitas Islam Kalimantan Muhammad Arsyad Al-Banjari Banjarmasin 


\section{PENDAHULUAN}

Pembelajaran diartikan sebagai proses kerjasama antara guru dan siswa dalam memanfaatkan potensi dan sumber yang ada, baik potensi yang bersumber dari dalam diri siswa itu sendiri seperti minat, bakat dan kemampuan dasar yang dimiliki, termasuk gaya belajar maupun potensi yang ada di luar diri siswa seperti lingkungan, sarana dan sumber belajar sebagai upaya untuk mencapai tujuan belajar tertentu. Proses pembelajaran pendidik bertugas untuk mendorong, membimbing, dan memfasilitasi peserta didik untuk belajar mencapai tujuan. Pendidik juga bertanggung jawab untuk menelaah segala aktivitas yang terjadi di dalam kelas guna membantu proses perkembangan peserta didik (Slameto, 2010:97). Sebagai suatu proses kerja sama, pembelajaran tidak hanya menitikberatkan pada kegiatan guru atau kegiatan siswa saja, tetapi guru dan siswa secara bersama-sama berusaha mencapai tujuan pembelajaran yang telah ditentukan. Oleh karena itu hasil belajar siswa adalah cermin dari pengetahuan, keterampilan dan sikap yang diperoleh siswa dalam mengikuti proses belajar mengajar. Prestasi belajar merupakan hasil belajar yang telah diukur dan ditunjukkan dengan rangkaian nilai dari satu periode hingga periode lain (Jamaliah, 2020:3).

Perkembangan teknologi telah menjanjikan potensi besar dalam merubah cara seseorang untuk belajar, untuk memperoleh informasi, menyesuaikan informasi dan sebagainya. Multimedia juga menyediakan berbagai peluang kepada para pengajar untuk mengaplikasikan berbagai metode pengajaran dan memberikan pilihan pada siswa untuk menentukan teknik belajar yang sesuai dengan keinginan mereka, yaitu pengalaman, suasana belajar yang menarik dan berkesan. Perpaduan yang tepat antara pemilihan metode pembelajaran dengan media yang digunakan akan menciptakan sebuah pembelajaran yang menarik.

Model tutorial adalah pembelajaran melalui komputer dimana siswa dikondisikan untuk mengikuti alur pembelajaran yang sudah terprogram dengan penyajian materi dan latihan soal, dalam hal ini dapat disimpulkan video tutorial adalah rangkaian pembelajaran melalui komputer dimana siswa dikondisikan untuk mengikuti alur pembelajaran yang sudah terprogram dengan penyajian materi dan latihan soal berbasis audio visual untuk membantu pemahaman siswa terhadap suatu materi pembelajaran sebagai bimbingan atau bahan pengajaran tambahan kepada sekelompok kecil peserta didik atau siswa (Kusuma, 2015:2). Dengan pembelajaran yang menarik, tentu akan menimbulkan kesan yang positif dalam diri peserta didik sehingga materi yang disampaikan akan terus dipahami dan tidak hilang begitu saja seiring dengan tersampaikannya materi-materi baru.

Berdasarkan ulasan latar belakang di atas, maka peneliti berkeinginan menerapkan video tutorial untuk membantu Meningkatkan Hasil Belajar Push Up, Sit Up dan Pull pada Mahasiswa PJKR UKAW Kupang.

\section{METODE}

Penelitian yang digunakan adalah Penelitian Tindakan Kelas (PTK) atau Classroom Action Research (CAR). Tindakan yang direncanakan berupa penerapan video tutorial guna meningkatkan hasil belajar push up, sit up, dan pull up. Pelaksanaan penelitian ini meliputi Siklus I dan II dengan prosedur yang digunakan dalam penelitian ini meliputi: perencanaan, pelaksanaan, observasi dan refleksi. Teknik pengumpulan data yang digunakan dalam penelitian ini adalah observasi dan tes untuk mengetahui Hasil Belajar Push Up, Sit Up dan Pull pada

Dipublikasikan Oleh :

UPT Publikasi dan Pengelolaan Jurnal

Universitas Islam Kalimantan Muhammad Arsyad Al-Banjari Banjarmasin 


\begin{tabular}{|l|l|c|c|c|}
\hline & & & Sampel & $\%$ \\
\hline 1. & Baik sekali & $>80$ & 2 & 10 \\
\hline 2. & Baik & $75-79$ & 18 & 90 \\
\hline \multicolumn{3}{|c|}{$\sum$} & 20 & $100 \%$ \\
\hline
\end{tabular}

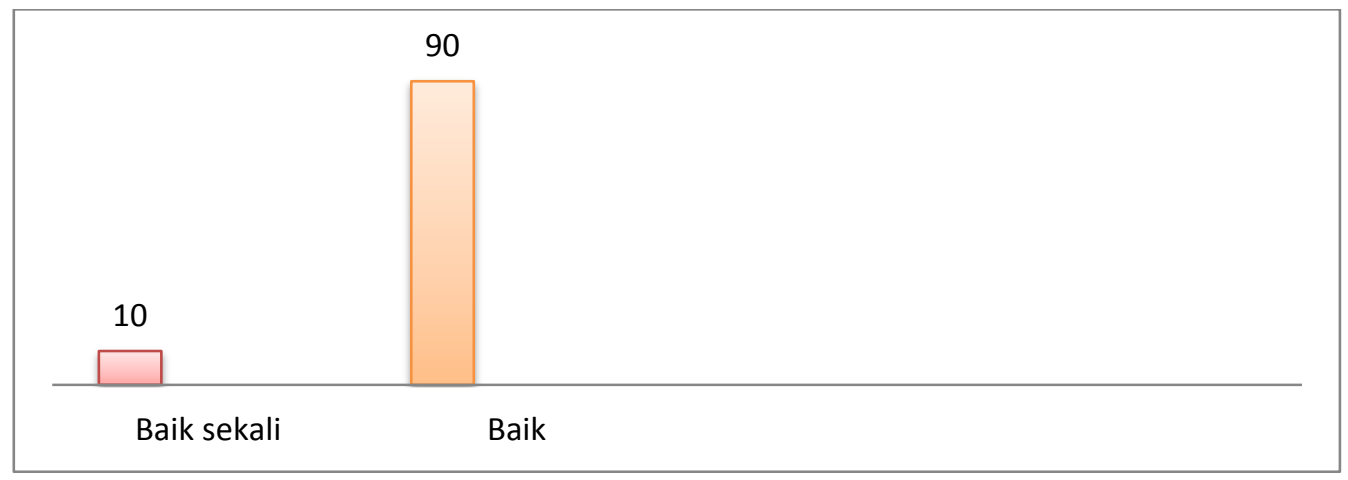

Gambar 2. Hasil Rekapitulasi Siklus I

\section{PENUTUP}

Berdasarkan hasil pengamatan dan hasil tes yang dilaksanakan untuk meningkatkan hasil belajar push up, sit up dan pull dengan video tutorial pada mahasiswa PJKR UKAW Kupang maka dapat disimpulkan bahwa video tutorial sangatlah membantu peserta didik dalam melaksanakan aktivitas tes sehingga hasil yang diperoleh dapat disimpulkan berhasil.

\section{REFERENSI}

\section{Buku1 Penulis}

Agus Suprijono. 2009. Cooperative Learning: Teori dan Aplikasi PAIKEM. Yogyakarta : Pustaka Pelajar Arikunto, Suharsimi. 2010. Prosedur Penelitian; Suatu Pendekatan Praktek Jakarta : PT . Rineka Cipta. Harimurti, Kridalaksana. 1990. Kelas Kata dalam Bahasa Indonesia. Jakarta: Gramedia.

Trianto. 2007. Model-model Pembelajaran Inovatif berorientasi Konstruktivistik. Jakarta : Prestasi Pustaka Publisher.

\section{Buku2 Penulis}

Dimyati dan Mudjiono. 2009. Belajar dan Pembelajaran. Jakarta : Rineka Cipta.

Fenanlampir Albertus, Faruq Muhammad Muhyi. 2015. Tes dan Pengukuran Dalam Olahraga. Yogyakarta: CV Andi Offset.

Syaiful Bahri Djamarah, dkk. 2002. Psikologi Belajar. Jakarta: Rineka Cipta

\section{Artikel Jurnal/Ensiklopedi}

Jamaliah, Naimatul. 2020. Peningkatan Hasil Belajar Passing Bawah Bola Voli Melalui Torgamba Kabupaten Labuhan Batu Selatan Model PBBT dan PBKL Siswa Kelas VIII SMPN 1 . Riyadhoh Jurnal Pendidikan Olahraga Vol 3, No 2 (1-8).

Rosadi Didin, Hardiansyah Luqman, Rusdiana Agus. 2018. Pengembangan Teknologi Alat Ukur Push Up Berbasis Microcontroller dengan Sensor Ultrasonic. Jurnal Terapan Ilmu Keolahragaan Vol 3 No 1 Tahun 2018 (34 - 39).

Sumantri, Ucu. 2019. Penggunaan video tutorial dalam upaya meningkatkan prestasi belajar tik pada siswa kelas xii.ips-1. Metaedukasi vol. 1, no. 2, 2019 (52-59)

Dipublikasikan Oleh :

UPT Publikasi dan Pengelolaan Jurnal

Universitas Islam Kalimantan Muhammad Arsyad Al-Banjari Banjarmasin 
Sahrul. 2018. Pengaruh Latihan Sit Up, Latihan Back Lift Dan Percaya Diri Terhadap Kemampuan Menyundul Bola Pada Permainan Sepakbola Siswa Sma Negeri 3 Bantaeng. Artikel PROGRAM PASCASARJANA UNIVERSITAS NEGERI MAKASSAR

Widayati, A. 2008. Penelitian Tindakan Kelas. Jurnal Pendidikan Akuntansi Indonesia, 4(1) 87-93.

\section{Skripsi/Tesis/Disertasidari Sumber Online}

Adiar, Yuditya Akmal. 2017. Implementasi Video Tutorial Sebagai Bahan Ajar Untuk Meningkatkan Hasil Belajar Pada Materi Pokok Membangun Jaringan Siswa Kelas X Jurusan Teknik Komputer Dan Jaringan (TKJ) Sekolah Menengah Kejuruan (Smk) Al-Islam Surakarta. Skripsi. Jurusan Kurikulum dan Teknologi Pendidikan Fakultas Ilmu Pendidikan Universitas Negeri Semarang

Dipublikasikan Oleh :

UPT Publikasi dan Pengelolaan Jurnal

Universitas Islam Kalimantan Muhammad Arsyad Al-Banjari Banjarmasin 